\title{
Hyperoxia Causes Inducible Nitric Oxide Synthase-Mediated Cellular Damage to the Immature Rat Brain
}

\author{
THOMAS HOEHN, URSULA FELDERHOFF-MUESER, KATJA MASCHEWSKI, \\ CHRISTINE STADELMANN, MARCO SIFRINGER, PETRA BITTIGAU, PETRA KOEHNE, \\ MARC HOPPENZ, MICHAEL OBLADEN, AND CHRISTOPH BÜHRER
}

Departments of Neonatology [T.H., U.F.-M., K.M., P.K., M.H., M.O., C.B.], Neuropediatrics [M.S., P.B.], and Neuropathology [C.S.], Humboldt University, Charité Virchow Hospital, D-13353 Berlin, Germany.

\section{ABSTRACT}

\begin{abstract}
Relative hyperoxia is a condition frequently encountered in premature infants, either spontaneously or during treatment in the Neonatal Intensive Care Unit. The effects of high inspiratory oxygen concentrations on immature brain cells and their signaling cascades are largely unknown. The aim of the study was to investigate the effect of hyperoxia on the amount and topographic distribution of iNOS-expression (inducible nitric oxide synthase) in the immature rat brain, and to localize hyperoxia-induced formation of peroxynitrite as a potential marker of cellular damage to immature cerebral structures. Seven-day-old Wistar rat pups were exposed to $>80 \%$ oxygen for $24 \mathrm{~h}$ and were then transcardially perfused. Following paraformaldehyde fixation, brains were paraffin-embedded and immunohistochemically stained for iNOS and nitrotyrosine. iNOS protein was quantified by Western blot; iNOS mRNA expression was studied by RTPCR. Total brain iNOS mRNA was up-regulated, demonstrating a peak at $6 \mathrm{~h}$ following the onset of hyperoxia. Immunohistochemical staining was predominantly observed in microglial cells of hippocampus and frontal cortex with some iNOS reactivity in endothelial and perivascular cells. Nitrotyrosine staining was positive in apical dendrites of neurons in the frontal cortex.
\end{abstract}

There was no positive staining for iNOS or nitrotyrosine in control animals. Hyperoxia causes iNOS mRNA and protein up-regulation in microglial cells of the immature rat brain. Positive neuronal nitrotyrosine staining indicates formation of peroxynitrite with potential deleterious effects for immature cellular structures in the neonatal brain. (Pediatr Res 54: 179-184, 2003)

CFR, frontal cortex
eNOS, endothelial NO synthase
HIP, hippocampus
iNOS, inducible NO synthase
MOP, primary motor cortex
MOS, secondary motor cortex
MSN, medial septal nucleus
nNOS, neuronal NO synthase
NO, nitric oxide
RSC, retrosplenial cortex
THA, thalamus

The role of NO has been subject of numerous investigations during recent years. This applies to its function as a gaseous messenger molecule and to its vasodilative properties. NO is released by hydroxylation of nitrogen at the guanidino group of L-arginine, a reaction which is catalyzed by the enzyme NO synthase (NOS). At least three isoforms of NOS are known at the moment, two constitutive forms (endothelial NOS and neuronal NOS) and the inducible form (iNOS). The latter is induced by bacteria and cytokines. NO

Received August 7, 2002; accepted December 16, 2002

Correspondence: Thomas Hoehn, M.D., Ph.D., Neonatology and Pediatric Intensive Care, University Children's Hospital, Heinrich-Heine-University, Moorenstr. 5, 40225 Düsseldorf, Germany; e-mail: thomas.hoehn@uni-duesseldorf.de

This study was supported by a grant from the Federal Department of Research and Technology (BMBF \#01 ZZ 0101), by intramural research aid from the Charité Faculty of Medicine (\#89522104), and by the Sonnenfeld-Stiftung. concentrations produced by iNOS are much higher than those generated by constitutive NOS (1), and have been shown to exert antimicrobial effects against some bacterial pathogens in vitro (2).

As soon as NO is generated in the target cell (cancer cell, parasite), binding at copper and iron containing proteins takes place (3). As a result copper and iron are released and, in combination with oxygen, toxic radicals are formed. This is referred to as "massive oxidative injury" and requires the expression of iNOS leading to the production of huge amounts of NO, whereas low levels of NO synthesized by the constitutive forms of NOS (eNOS, nNOS) act as a signal molecule (4). Thus, the concentration of NO determines its biologic effect upon neighboring cells and tissues. The reaction products of nitrogen and oxygen include the strong oxidant peroxyni- 
trite, which is the result of the interaction of NO and superoxide anion (4).

The enzyme iNOS is predominantly expressed in macrophages in response to inflammatory stimuli. Induction occurs by bacteria, bacterial products and cytokines (5). At least in lung tissue NO can exert both pro-oxidant and antioxidant effects (6). Again the ultimate response of the lung most likely depends on the dose of $\mathrm{NO}$ administered and the presence of other reactive intermediates (7). At low levels of NO production, antioxidant properties of NO predominate. However, with high or sustained generation of NO due to up-regulation of iNOS or administration of exogenous NO, cytotoxic reactive nitrogen intermediates can be formed (8). In the brain, iNOS expression has been characterized in astrocytes, microglial cells, and to a lesser extent in endothelial cells $(9-12)$. In numerous disease states, beneficial as well as deleterious effects have been attributed to the production of NO by glial iNOS.

Hyperoxia in combination with increased production of $\mathrm{NO}$ has been shown to induce cell death and DNA fragmentation in pulmonary tissue (13). This latter effect has been attributed to the formation of peroxynitrite, which results from the reaction of the superoxide anion with NO $(14,15)$. Peroxynitrite, neither NO nor superoxide, can nitrite tyrosine residues of proteins and form the stable product 3-nitrotyrosine (16). This reaction occurs spontaneously but is also catalyzed by superoxide dismutase or carbon dioxide (17-19).

The effects hyperoxia on the immature retina (20) and lungs (21-23) have been extensively investigated. However, data on the effect of hyperoxia on the immature brain, although scarce, indicate that it may lead to damage in the premature brain (24). Having in mind the steep postnatal increase in oxygen tension (intrauterine $\mathrm{pO}_{2}: 27-35 \mathrm{~mm} \mathrm{Hg}$, postnatal $\mathrm{pO}_{2}: 40-100 \mathrm{~mm}$ $\mathrm{Hg}$ ), we set out to investigate effects of hyperoxia on iNOS expression in immature brain tissue.

We hypothesized that hyperoxia induces iNOS expression in the immature rat brain and sought to determine the cellular source of iNOS. Furthermore we intended to determine whether up-regulation of iNOS leads to increases in 3-nitrotyrosine, which would point toward peroxynitrite-mediated cellular damage.

\section{MATERIALS AND METHODS}

Animals and oxygen exposure. Seven-day-old Wistar rat pups were housed with their dames. Altogether 138 rat pups derived from 11 litters were investigated, the number of animals in each experiment varied depending on the size of the individual litter (8 to 24). Oxygen exposure was achieved by placing the animals in an oxygen chamber with a minimal $\mathrm{FiO}_{2}$ of 0.8 for a duration of $24 \mathrm{~h}$ ( $\geq 80 \%$ oxygen, $<1 \%$ carbon dioxide, rest nitrogen). Control animals were kept at room air. There were no hyperoxia-associated symptoms in the rat pups, mortality rate was $<5 \%$ in both groups. Following oxygen exposure the pups were anesthetized and subsequently killed. Brains were perfused transcardially with heparinized PBS followed by paraformaldehyde (4\%) as described previously (25). Briefly, following thoracotomy and right atrial incision the perfusion needle was advanced into the ascending aorta. After PBS and paraformaldehyde perfusion $(20 \mathrm{~mL}$ each) continuous perfusion with cold paraformaldehyde (4\%) was performed for at least $10 \mathrm{~min}$. Brains were stored in paraformaldehyde for a total of 3-7 d, thereafter moved to acidified PBS and embedded in paraffin.

Fresh brain tissue for RT-PCR was stored at minus $70^{\circ} \mathrm{C}$ following decapitation.

All experiments were performed in accordance with the German Animal Welfare Act and were approved by the local Animal Protection Authority.

$\boldsymbol{R T}$-PCR. Whole brains were quickly removed following decapitation, cut into six anatomically defined areas (striatum, hippocampus, frontal cortex, cerebellum, thalamus, retrosplenial cortex), and frozen at minus $70^{\circ} \mathrm{C}$ until analysis. RNA was isolated by the use of RNeasy ${ }^{\circledR}$ (Qiagen, Bothell, Washington, U.S.A.), a concentration of $0.1 \mu \mathrm{g} / \mu \mathrm{L}$ was aimed at in all specimens. Briefly, approximately $80 \mathrm{mg}$ of rat brain tissue were homogenized for $30 \mathrm{~s}$ and added to $1 \mathrm{~mL}$ RLT-buffer and $10 \mu \mathrm{L} \beta$-mercaptoethanol. Lysates were centrifuged at 5000 $\mathrm{rpm}$ at $4^{\circ} \mathrm{C}$ for $3 \mathrm{~min}$, for analysis $500 \mu \mathrm{L}$ of the supernatant were diluted with an equal amount of ethanol $70 \% .500 \mu \mathrm{L}$ of the lysate-ethanol-mixture were put on top of the spin column (RNeasy ${ }^{\circledR}$ mini) and subsequently centrifuged at $10,000 \mathrm{rpm}$ at $4^{\circ} \mathrm{C}$ for $15 \mathrm{~s}$. The percolation was discarded, then the whole procedure was repeated with the remainder of the lysateethanol-mixture. Again the percolation was discarded. RW1 buffer $(700 \mu \mathrm{L})$ was added to the column, which was spun down at 10,000 rpm for $15 \mathrm{~s}$. A new $2 \mathrm{~mL}$ container was connected to the RNeasy® mini spin column, filled with 500 $\mu \mathrm{L}$ RPE buffer, and then centrifuged at $10,000 \mathrm{rpm}$ for $15 \mathrm{~s}$. After discarding the percolation, the whole procedure was repeated with equal amounts of RPE buffer, at this step the spin down was performed for $4 \mathrm{~min}$ at 13,000 rpm. For eluation of the RNA from the column another $1.5 \mathrm{~mL}$ container was used. Fifty microliters of RNAse-free water was pipetted onto the membrane and thereafter centrifuged at 13,000 rpm for $5 \mathrm{~min}$. This procedure was repeated once. The resulting volume of extracted RNA was approximately $100 \mu \mathrm{L}$. The concentration of RNA was measured photometrically (E260/E280), if required the concentration was modified to achieve $0.1 \mu \mathrm{g} / \mu \mathrm{L}$.

Reverse transcription of $1 \mu \mathrm{g}$ RNA into cDNA was performed by use of random hexamers and AMV reverse transcriptase and $1 \times$ PCR buffer $(20 \mathrm{mM}$ Tris $\cdot \mathrm{HCl}, \mathrm{pH} 8.3,50$ $\mathrm{mM} \mathrm{KCl}, 2 \mathrm{mM} \mathrm{MgCl}$, and $100 \mu \mathrm{g} / \mathrm{mL}$ BSA). The cDNA was amplified by PCR in a total volume of $30 \mu \mathrm{L}$ with the use of $5 \mathrm{U} / \mu \mathrm{L}$ Taq DNA polymerase (GIBCO, Eggenstein, Germany). Furthermore $4 \mu \mathrm{L} 1 \mathrm{mM}$ dNTP, $0.75 \mu \mathrm{L} \mathrm{MgCl}(20 \mathrm{mM})$, $5 \mu \mathrm{L}$ 10xPCR-Puffer, 15.6 $\mu \mathrm{L}$ Aqua and $1 \mu \mathrm{L}$ of each primer were added.

Amplification was achieved in a microprocessor-driven thermocycler (Multicycler PTC-200 MJ Research, Biozym, Hessisch Oldendorf, Germany).

Primers of the housekeeping gene ( $\beta$-actin) had the following sequences (PCR-product: 897 bp): 5'-CCC TAA ggC CAA CCg TgA AAA gAT g-3' (sense; 1663-1687nt) and gAA CCg CTC ATT gCC gAT AgT gAT g-3' (antisense; 2535-2559nt). Amplification of $\beta$-actin was terminated after 30 cycles $\left(30^{\prime \prime}\right.$ at 
$94^{\circ} \mathrm{C}, 60^{\prime \prime}$ at $60^{\circ} \mathrm{C}$ and $60^{\prime \prime}$ at $72^{\circ} \mathrm{C}$ ). Sequences of iNOSprimers were (PCR-product: $388 \mathrm{bp}$; MWG-Biotech, Ebersberg, Germany): 5'-AgC ATC ACC CCT gTg TTC CAC CC-3' (sense; 1592-1613nt) and 5'-Tgg ggC AgT CTC CAT TgC CA-3' (antisense; 1979-1960nt). Again 30 cycles were run for the iNOS-PCR $\left(30^{\prime \prime}\right.$ at $94^{\circ} \mathrm{C}, 60^{\prime \prime}$ at $60^{\circ} \mathrm{C}$ and $60^{\prime \prime}$ at $\left.72^{\circ} \mathrm{C}\right)$. PCR-products were separated by gel electrophoresis (agarose $2 \%$ ), stained with ethidium bromide and subsequently exposed to UV light.

iNOS-Western blot. For Western blotting analysis of brain tissue, animals were killed, and brains were removed, microdissected, and immediately snap frozen in liquid nitrogen.

Tissue was then homogenized at $4^{\circ} \mathrm{C}$ in a Tris-HCL buffer (50 mM, pH 7.6) containing: $150 \mathrm{mM} \mathrm{KCL}, 5 \mathrm{mM}$ ethylene diamine tetraacetic acid (EDTA), $1 \mathrm{mM}$ phenylmethane sulfonyl fluoride (PMSF), $1 \%$ Triton X-100, $0.5 \mu \mathrm{g} / \mathrm{mL}$ leupeptin and $1 \mu \mathrm{g} / \mathrm{mL}$ pepstatin. Homogenate was centrifuged at 15,000 $g$ for $20 \mathrm{~min}$ and the supernatant used as the cytosolic fraction.

Total cellular proteins $(25 \mu \mathrm{g} / \mathrm{lane}$ cytosolic fraction) were separated on a $10 \%$ SDS-polyacrylamide gel and electrotransferred onto nitrocellulose membranes (Hybond ECL, Amersham International, Bucks, U.K.). Equal loading and transfer of proteins was confirmed by temporally staining the membranes with Ponceau S solution. The nonspecific binding of proteins was prevented by treating the membranes with $5 \%$ nonfat dry milk in Tris-buffered saline/ $0.1 \%$ Tween 20 for $2 \mathrm{~h}$ at room temperature. The membranes were incubated overnight at $4{ }^{\circ} \mathrm{C}$ with anti-iNOS antibody (1:10,000; Transduction Laboratories). After incubation with secondary antibody conjugated to horseradish peroxidase (anti-mouse, 1:2000 dilution), immunoreactive proteins were detected by the enhanced chemiluminescence system (ECL, Amersham International) and serial exposures were made to radiographic film (Hyperfilm ECL, Amersham International). Densitometric analysis of the blots was performed with the image analysis program TINA $2.09 \mathrm{~g}$.

Immunocytochemistry. Paraffin-embedded serial coronal sections were cut at a thickness of $10 \mu \mathrm{m}$ (Leica microtome VT 1000S, Leica, Nussloch, Germany) and mounted on silanecoated slides. The anti-iNOS-antibody was purchased from Santa Cruz (Cat.-No. Sc-7271, Santa Cruz, CA, U.S.A.), the anti-nitrotyrosine antibody was acquired from Upstate Biotechnology (Cat.-No. 06-284, Upstate, Lake Placid, NY, U.S.A.). Antibodies were used in concentrations of 1:100 (iNOS) and 1:200 (nitrotyrosine), respectively. In brief, sections were initially deparaffinized by washing in xylene and decreasing ethanol concentrations, then boiled in citrate buffer to unmask antigen sites. Following cooling with tap water, slides were washed in PBS. Endogenous peroxidase activity was blocked by exposing slides to $0.6 \%$ hydrogen peroxide in PBS for 30 min. After washing in PBS nonspecific binding was avoided by incubation with 5\% blocking solution (5\% normal goat serum in PBS) for $20 \mathrm{~min}$. Sections were incubated overnight with the respective primary antibody. Following removal of the antibody and repetitive rinsing with PBS, slides were incubated with a biotinylated goat anti-rabbit IgG antibody (1:200, Vector Laboratories, Burlingame, CA, U.S.A.). Immunocytochemical identification of positive cells was performed by the use of an avidin-biotinylated peroxidase complex (ABC-kit Vec- tastain, Vector Laboratories, Burlingame, CA, U.S.A.) and DAB substrate (Vector Laboratories, Burlingame, CA, U.S.A.). After intensive washing in PBS and Tris buffer slides were counterstained with methyl green $10 \%$ or hematoxylin, respectively. Sections were washed with butanol, treated with xylene and subsequently mounted. All specimens were examined by light microscopy (CH2, Olympus, Shinjuku-ku, Tokyo, Japan), photographs were taken with a digital camera (C-3030, Olympus, Shinjuku-ku, Tokyo, Japan).

Light microscopy. Light microscopy was performed with a conventional microscope (CH2 or BX60, Olympus, Shinjuku$\mathrm{ku}$, Tokyo, Japan). Brain regions examined were:

In anterior brain areas primary motor cortex (MOP), secondary motor cortex (MOS), and medial septal nucleus (MSN) [Fig. 1, left]

In posterior brain areas retrosplenial cortex (RSC), hippocampus (HIP) including regions CA1 and CA3, and thalamus (THA) [Fig. 1, right].

Statistical analysis. Data are shown as mean and SEM. Statistical evaluation was performed using the Wilcoxon test, significant differences between control and hyperoxia animals were assumed at $p<0.05$.

\section{RESULTS}

iNOS-immunohistochemistry. Whereas there was only occasional staining in perivascular areas in controls, iNOSpositive staining was present in all hyperoxia-exposed animals. Staining was confined to microglial cells as evident from the typical microscopic shape and appearance. Positive cells were predominantly present in the retrosplenial cortex (Fig. 2), hippocampus (Fig. 3), and frontal cortex (Fig. 4), less so in the thalamus (Fig. 5).

Nitrotyrosine-immunohistochemistry. Staining was strongly positive in some neurons in the frontal cortex, other neurons remained unstained. Particularly apical dendrites showed marked staining (Fig. 6), this was confined to neurons within the frontal cortex.

iNOS-RT-PCR. Expression of iNOS was only slightly increased $2 \mathrm{~h}$ after the onset of hyperoxia, significantly so at $6 \mathrm{~h}$ and $12 \mathrm{~h}$ (Fig. 7). iNOS-mRNA had a similar time course in
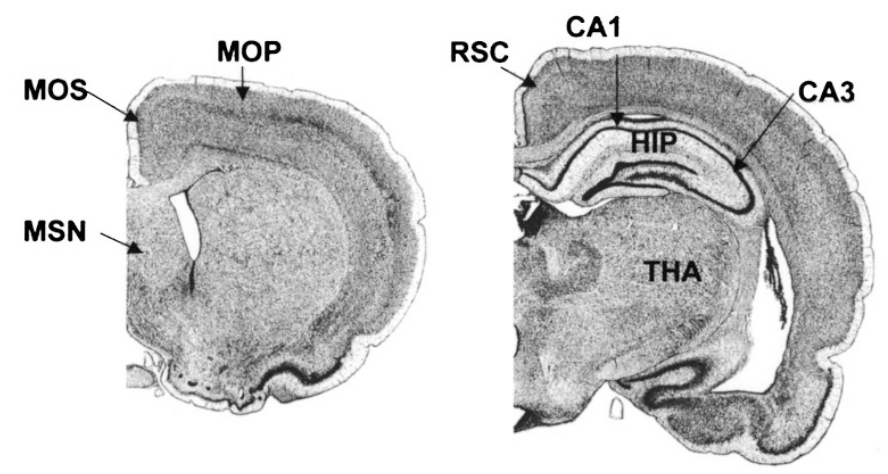

Figure 1. Anterior and posterior rat brain slices of the areas investigated (MOP: primary motor cortex; MOS: secondary motor cortex; RSC: retrosplenial cortex; HIP: hippocampus with areas CA1 and CA3; THA: thalamus; MSN: medial septal nucleus). 


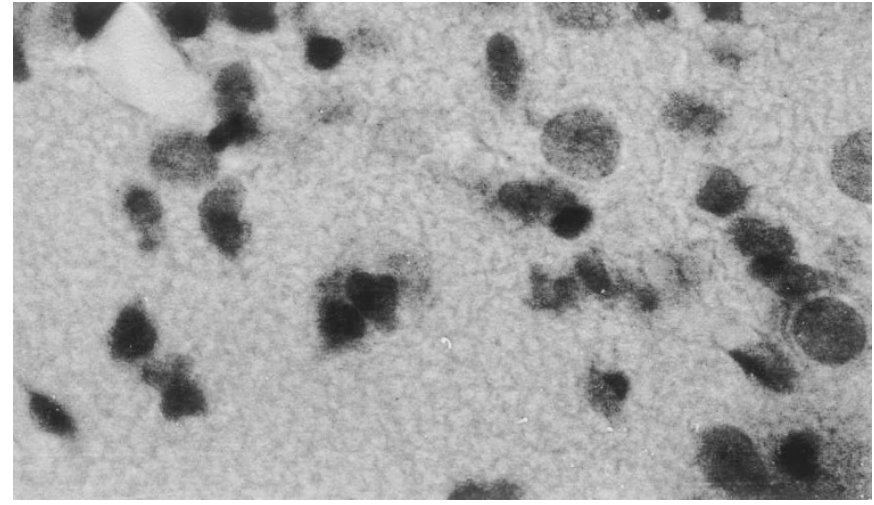

Figure 2. iNOS immunohistochemistry in the hippocampus $(1000 \times)$ of the 7-day-old control rat without evidence of specific staining.

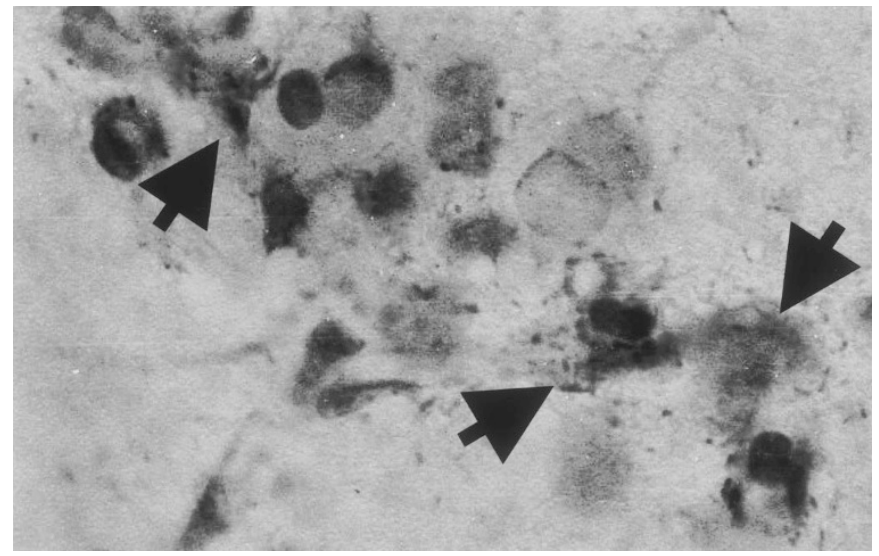

Figure 3. iNOS immunohistochemistry in the hippocampus $(1000 \times)$ of the 7-day-old hyperoxia-exposed rat with brown staining of microglial cells (black arrows).

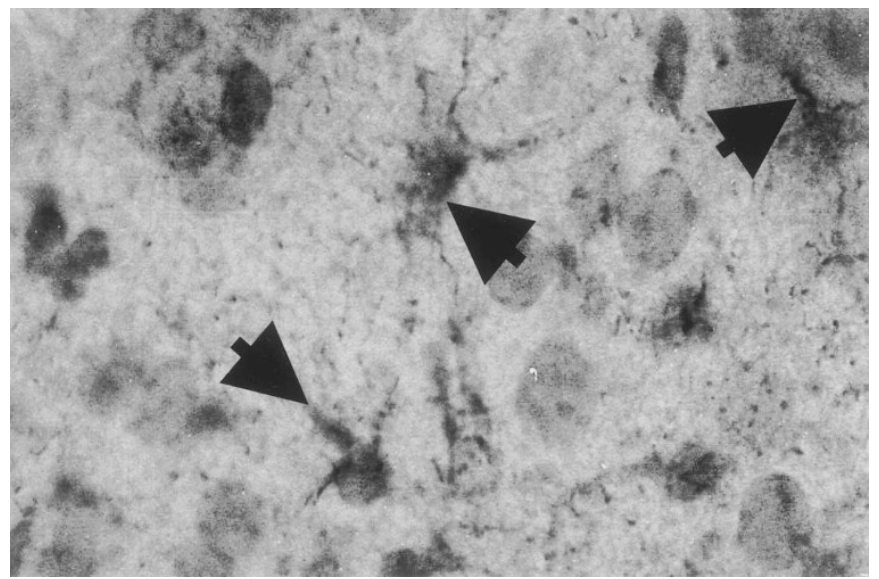

Figure 4. Frontal cortex (iNOS staining; 1000×) in the 7-day-old hyperoxiaexposed rat; note reticular pattern of staining confined to microglial cells (black arrows).

frontal cortex and thalamus, after $24 \mathrm{~h}$ of oxygen exposure iNOS expression was almost back to initial levels.

iNOS-Western blot. Expression of iNOS protein was significantly increased in retrosplenial cortex and hippocampus after $24 \mathrm{~h}$ of hyperoxia ( $t$ test), iNOS expression in control animals was set as $100 \%$ (Fig. 8).

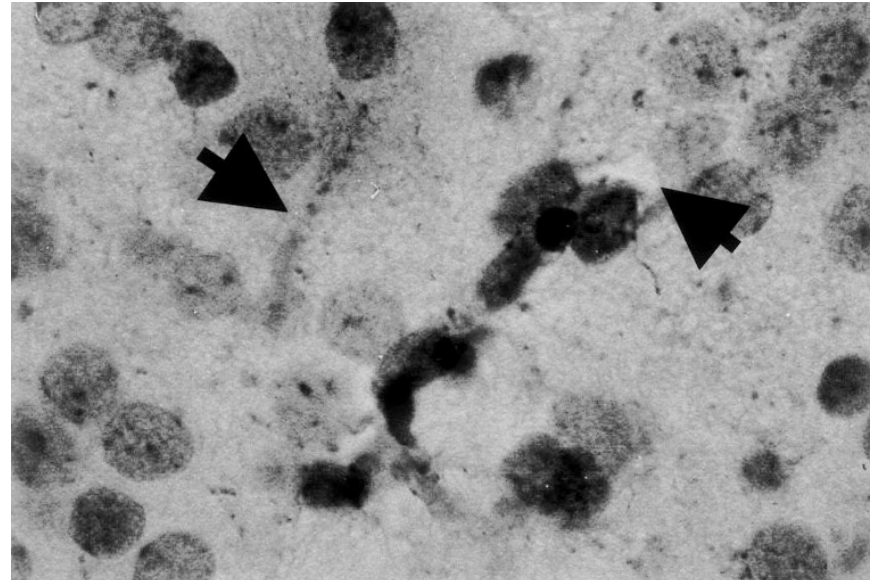

Figure 5. Thalamus (iNOS staining; $1000 \times$ ) in the 7-day-old hyperoxiaexposed rat; microglial cells stain positive as visible by the brown, net-like appearance (black arrows).

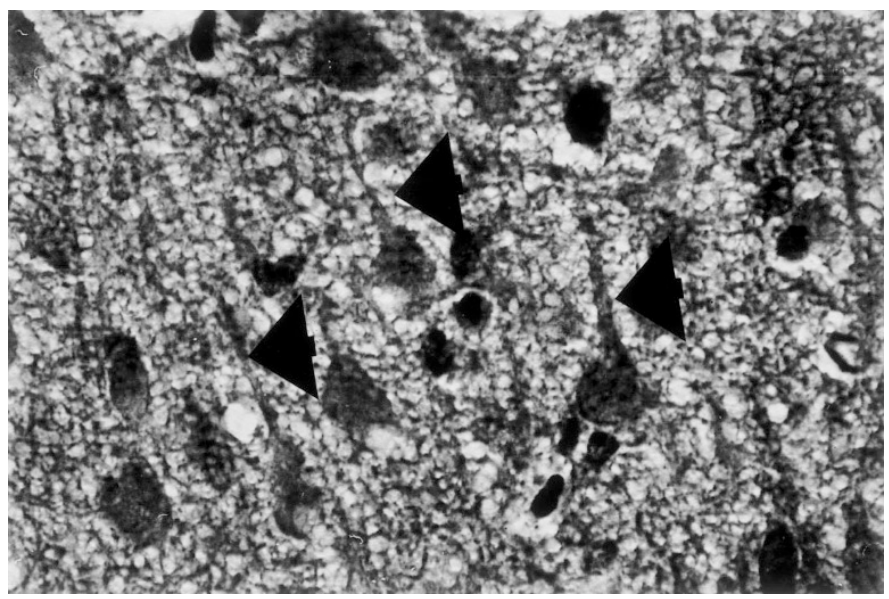

Figure 6. Nitrotyrosine staining (frontal cortex, 1000×) in the hyperoxia treated 7-day-old rat pup; staining is most pronounced in neurons and their apical dendrites (black arrows).

\section{DISCUSSION}

Here we demonstrate up-regulation of iNOS and subsequent peroxynitrite formation in different areas and cell types in the immature rat brain previously exposed to hyperoxia. Whereas iNOS protein staining was confined to microglial and to a lesser extent to endothelial cells, peroxynitrite formation took place in apical dendrites of neurons. This differential observation is supported by in vitro co-cultures of activated microglia and embryonic cortical neurons, in which microglia was shown to produce nitric oxide and adjacent neurons exhibited neurodegenerative damage (26).

Exposure to high oxygen concentrations has long been known to cause pulmonary morbidity $(21,27,28)$. It has been shown that hyperoxia serves as a potent trigger of upregulation of iNOS mRNA expression in pulmonary cells within several hours of oxygen exposure in mice (29) as well as in rats (30). When wild-type animals were compared with iNOS-deficient mice, lung injury was more severe in iNOSdeficient animals indicating a protective effect of iNOS due to reduction of pulmonary leukocyte accumulation. Since nitrotyrosine was detectable in both wild type and iNOS deficient 


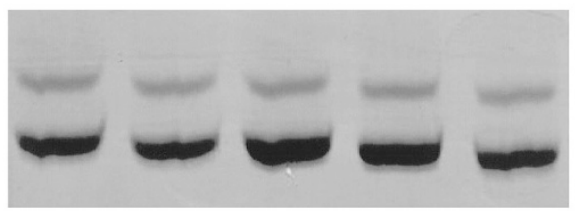

Control $2 \mathrm{~h} \quad 6 \mathrm{~h} \quad 12 \mathrm{~h} \quad 24 \mathrm{~h}$

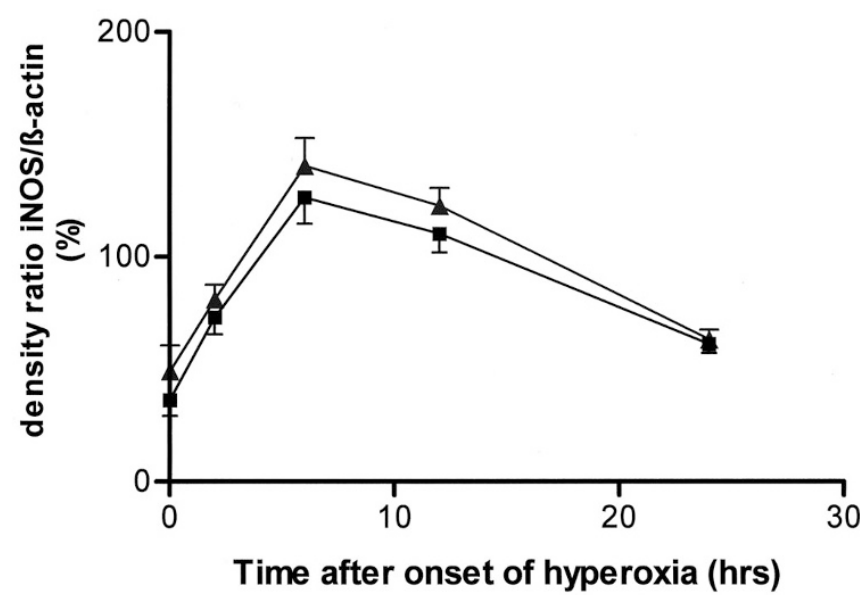

Figure 7. Time course of iNOS-mRNA expression (RT-PCR) during the first $24 \mathrm{~h}$ of hyperoxia exposure in frontal cortex (square and original blot) and thalamus (triangle) $(n=6)$.

\section{iNOS expression}

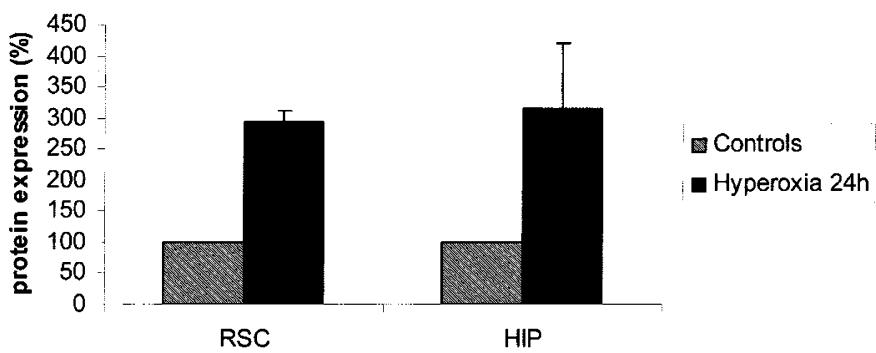

Figure 8. iNOS protein expression (Western blot) of controls $(n=7)$ and 24 h hyperoxia exposure $(n=7)$ for the brain regions retrosplenial cortex (RSC) and hippocampus (HIP).

mice following hyperoxia, existence of an iNOS-independent pathway for protein nitration was concluded (29).

Once the effects of hyperoxia on distant organs are investigated (for example the brain), matters become more complicated. Although there is evidence that hyperoxemia leads to reduced cerebral blood flow in several animal models, information about resulting tissue oxygen tensions remains scarce (31). In a rat model of 2-day-old pups the combined effect of hyperoxia and inhibition of glutathione synthesis led to an increased amount of histologically detectable apoptosis (32). Other distant organs have been investigated with respect to the integrity of their anti-oxidant capacities. In the isolated perfused rat liver hyperoxia not only led to up-regulation of iNOS protein and mRNA levels, but also to impaired anti-oxidant defense mechanisms as indicated by reduced intracellular glutathione levels (33).
Focal ischemia and reperfusion after $1 \mathrm{~h}$ in a newborn rat model increased immunohistochemical iNOS and nitrotyrosine staining in neutrophils and perivascular endothelial cells at the age of $72 \mathrm{~h}$ (34). This shows that nonresident cells (neutrophils) as well as resident brain cells (perivascular endothelial cells) contribute to the intracerebral formation of peroxynitrite. Unfortunately from the experimental set-up of the model, no differentiation between the underlying triggers for nitration of tyrosine residues can be made (ischemia versus reperfusion i.e. relative hyperoxia).

In a different model of hypoxia-ischemia the authors found increased amounts of iNOS and nitrotyrosine in the infarct area. They were also able to reduce iNOS-mediated damage by the use of S-methyl-isothiourea (a selective inhibitor of iNOS) (35). Although the causative effect of iNOS up-regulation on the resulting brain damage could be demonstrated by specific inhibition, caution is warranted as to what caused the increase in iNOS-mRNA expression in the first place (hypoxia-ischemia or subsequent reoxygenation, in this case with room air).

Both of these aforementioned rat models investigated effects of hypoxia-ischemia with subsequent reoxygenation in the immature rat brain. The maturity of cerebral structures of the 7-day-old rat corresponds approximately to that of the human fetus during the last trimester of pregnancy. This approximation is derived from the temporal assignment of the brain growth spurt in man and rat, which equates the period of the growth spurt with the maximal vulnerability of cerebral integrity (36). In our experimental model we used animals of the same postnatal age, but modified our intervention to a single procedure i.e. hyperoxia. To our knowledge this is the first investigation of the hyperoxia effect on iNOS expression in the immature rat brain. Earlier investigators looked at peroxynitrite formation in cortical glial cultures following iNOS induction (37), iNOS expression following intrastriatal injection of lipopolysaccharide $(38,39)$, or iNOS expression following traumatic brain injury in immature (40) and adult rats (41-43).

Authors of a porcine model of inflammation concluded that their finding of only minimal induction of iNOS but intense nitrotyrosine immunostaining indicates the existence of alternative pathways of nitrotyrosine production (44).

Since iNOS is not the sole enzyme catalyzing the synthesis of NO, particularly up-regulation of eNOS could lead to the formation of peroxynitrite without concomitant increases in iNOS protein. Activation of this pathway in the context of inflammation has been previously shown (45). Alternatively, nitrotyrosine could be produced by the reaction of tyrosine residues with other reactive molecules, such as perchloric acid, which is produced by infiltrating neutrophils and hydroxyl radicals from myeloperoxidase (46).

In vitro experiments have provided evidence of sufficient protection against nitration of tyrosine residues in the presence of physiologic levels of glutathione and carbon dioxide (47). Whether this is also true during in vivo conditions - particularly in immature animals - needs to be determined.

We conclude that hyperoxia induces up-regulation of iNOSmRNA and synthesis of iNOS-protein in microglial cells in several areas of the immature rat brain. This increased protein synthesis leads to the formation of peroxynitrite, which indi- 
cates potential damage to structures of the neonatal brain. Further research should address underlying mechanisms to identify endogenous and exogenous systems capable to protect the neonatal brain.

Acknowledgments. The authors thank Evy Strauss, Wolfgang Brück, Anthony Preston, and Roger Wadsworth for their practical and intellectual help with immunohistochemical methods.

\section{REFERENCES}

1. Cunha FQ, Assreuy J, Xu D, Charles I, Liew FY, Moncada S 1993 Repeated induction of nitric oxide synthase and leishmanicidal activity in murine macrophages. Eur J Immunol 23:1385-1388

2. Hoehn T, Huebner J, Paboura E, Krause M, Leititis JU 1998 Effect of therapeutic concentrations of nitric oxide on bacterial growth in vitro. Crit Care Med 26:18571862

3. Änggard E 2061994 Nitric oxide: mediator, murderer, and medicine. Lancet 343:1199-1206

4. Kröncke KD, Fehsel K, Suschek C, Kolb-Bachofen V 2001 Inducible nitric oxide synthase-derived nitric oxide in gene regulation, cell death and cell survival. Int Immunopharmacol 1:1407-1420

5. Weisz A, Cicatiello L 1996 Regulation of the mouse inducible-type nitric oxide synthase gene promoter by interferon-gamma, bacterial lipopolysaccharide and NGmonomethyl-L-arginine. Biochem J 316:209-215

6. Weinberger B, Weiss K, Heck DE, Laskin DL, Laskin JD 2001 Pharmacologic therapy of persistent pulmonary hypertension of the newborn. Pharmacol Ther 89:67-79

7. Liaudet L, Soriano FG, Szabo C 2000 Biology of nitric oxide signaling. Crit Care Med 28(4 Suppl):N37-52

8. Wink DA, Mitchell JB 1998 Chemical biology of nitric oxide: Insights into regulatory, cytotoxic, and cytoprotective mechanisms of NO. Free Radic Biol Med 25:434456

9. Heneka MT, Feinstein DL 2001 Expression and function of inducible nitric oxide synthase in neurons. J Neuroimmunol 114:8-18

10. Murphy S, Simmons ML, Agullo L, Garcia A, Feinstein DL, Galea E, Reis DJ, Minc-Golomb D, Schwartz JP 1993 Synthesis of nitric oxide in CNS glial cells. Trends Neurosci 16:323

11. Brosnan CF, Lee SC, Liu J 1997 Regulation of inducible nitric oxide synthase expression in human glia: implications for inflammatory central nervous system diseases. Biochem Soc Trans 25:679

12. Minghetti L, Levi G 1998 Microglia as effector cells in brain damage and repair: focus on prostanoids and nitric oxide. Prog Neurobiol 54:99

13. Raghuram N, Fortenberry JD, Owens ML, Brown LA 1999 Effects of exogenous nitric oxide and hyperoxia on lung fibroblast viability and DNA fragmentation. Biochem Biophys Res Commun 262:685-691

14. Koppenol WH, Moreno JJ, Pryor WA, Ischiropoulos H, Beckman JS 1992 Peroxynitrite, a cloaked oxidant formed by nitric oxide and superoxide. Chem Res Toxicol $5: 834-842$

15. Lee C, Miura K, Liu X, Zweier JL 2000 Biphasic regulation of leukocyte superoxide generation by nitric oxide and peroxynitrite. J Biol Chem 275:38965-38972

16. Demiryurek AT, Karamsetty MR, McPhaden AR, Wadsworth RM, Kane KA MacLean MR 2000 Accumulation of nitrotyrosine correlates with endothelial NO synthase in pulmonary resistance arteries during chronic hypoxia in the rat. Pulm Pharmacol Ther 13:157-165

17. Cross AR, Jones OTG 1991 Enzyme mechanisms of superoxide production. Biochim Biophys Acta 1057:281-298

18. Ischiropoulos H, Zhu L, Chen J, Tsai M, Martin JC, Smith CD, Beckman JS 1992 Peroxynitrite-mediated tyrosine nitration catalyzed by superoxide dismutase. Arch Biochem Biophys 298:431-437

19. Zhang H, Squadrito GL, Pryor WA 1997 The mechanism of the peroxynitrite-carbon dioxide reaction probed using tyrosine. Nitric Oxide 1:301-307

20. Bland RD 1980 Special considerations in oxygen therapy of infants and children. Am Rev Respir Dis 122:45-54

21. Chen Y, Whitney PL, Frank L 1994 Comparative responses of premature versus full-term newborn rats to prolonged hyperoxia. Pediatr Res 35:233-237

22. O'Donovan DJ, Fernandes CJ 2000 Mitochondrial glutathione and oxidative stress: implications for pulmonary oxygen toxicity in premature infants. Mol Genet Metab 71:352-358
23. Appleby CJ, Towner RA 2001 Magnetic resonance imaging of pulmonary damage in the term and premature rat neonate exposed to hyperoxia. Pediatr Res 50:502-507

24. Ahdab-Barmada M, Moossy J, Nemoto EM, Lin MR 1986 Hyperoxia produces neuronal necrosis in the rat. J Neuropathol Exp Neurol 45:233-246

25. Golde S, Chandran S, Brown GC, Compston A 2002 Different pathways for iNOSmediated toxicity in vitro dependent on neuronal maturation and NMDA receptor expression. J Neurochem 82:269-282

26. Ikonomidou C, Bosch F, Miksa M, Bittigau P, Vockler J, Dikranian K, Tenkova TI, Stefovska V, Turski L, Olney JW 1999 Blockade of NMDA receptors and apoptotic neurodegeneration in the developing brain. Science 283:70-74

27. Bucher JR, Roberts RJ 1981 The development of the newborn rat lung in hyperoxia: a dose-response study of lung growth, maturation, and changes in antioxidant enzyme activities. Pediatr Res 15:999-1008

28. Manji JS, O'Kelly CJ, Leung WI, Olson DM 2001 Timing of hyperoxic exposure during alveolarization influences damage mediated by leukotrienes. Am J Physio Lung Cell Mol Physiol 281:L799-806

29. Kobayashi H, Hataishi R, Mitsufuji H, Tanaka M, Jacobson M, Tomita T, Zapol WM, Jones RC 2001 Antiinflammatory properties of inducible nitric oxide synthase in acute hyperoxic lung injury. Am J Respir Cell Mol Biol 24:390-397

30. Radomski A, Sawicki G, Olson DM, Radomski MW 1998 The role of nitric oxide and metalloproteinases in the pathogenesis of hyperoxia-induced lung injury in newborn rats. Br J Pharmacol 125:1455-1462

31. Sjoberg F, Gustafsson U, Eintrei C 1999 Specific blood flow reducing effects of hyperoxaemia on high flow capillaries in the pig brain. Acta Physiol Scand 165:33-38

32. Taglialatela G, Perez-Polo JR, Rassin DK 1998 Induction of apoptosis in the CNS during development by the combination of hyperoxia and inhibition of glutathione synthesis. Free Radic Biol Med 25:936-942

33. Miralles C, Busquets X, Santos C, Togores B, Hussain S, Rahman I, MacNee W, Agusti AG 2000 Regulation of iNOS expression and glutathione levels in rat liver by oxygen tension. FEBS Lett 476:253-257

34. Coeroli L, Renolleau S, Arnaud S, Plotkine D, Cachin N, Plotkine M, Ben-Ari Y, Charriaut-Marlangue C 1998 Nitric oxide production and perivascular tyrosine nitration following focal ischemia in neonatal rat. J Neurochem 70:2516-2525

35. Ikeno S, Nagata N, Yoshida S, Takahashi H, Kigawa J, Terakawa N 2000 Immature brain injury via peroxynitrite production induced by inducible nitric oxide synthase after hypoxia-ischemia in rats. J Obstet Gynaecol Res 26:227-234

36. Dobbing J, Sands J 1979 Comparative aspects of the brain growth spurt. Early Hum Dev 3:79-83

37. Noack H, Possel H, Rethfeldt C, Keilhoff G, Wolf G 1999 Peroxynitrite mediated damage and lowered superoxide tolerance in primary cortical glial cultures after induction of the inducible isoform of NOS. Glia 28:13-24

38. Heneka MT, Dumitrescu L, Loschmann PA, Wullner U, Klockgether T 2000 Temporal, regional, and cell-specific changes of iNOS expression after intrastriatal microinjection of interferon gamma and bacterial lipopolysaccharide J Chem Neuroanat 18:167-179

39. Possel H, Noack H, Putzke J, Wolf G, Sies H 2000 Selective upregulation of inducible nitric oxide synthase (iNOS) by lipopolysaccharide (LPS) and cytokines in microglia: in vitro and in vivo studies. Glia 32:51-59

40. Clark RS, Kochanek PM, Schwarz MA, Schiding JK, Turner DS, Chen M, Carlos TM, Watkins SC 1996 Inducible nitric oxide synthase expression in cerebrovascular smooth muscle and neutrophils after traumatic brain injury in immature rats. Pediatr Res 39:784-790

41. Sinz EH, Kochanek PM, Dixon CE, Clark RS, Carcillo JA, Schiding JK, Chen M, Wisniewski SR, Carlos TM, Williams D, DeKosky ST, Watkins SC, Marion DW, Billiar TR 1999 Inducible nitric oxide synthase is an endogenous neuroprotectant after traumatic brain injury in rats and mice. J Clin Invest 104:647-656

42. Petrov T, Page AB, Owen CR, Rafols JA 2000 Expression of the inducible nitric oxide synthase in distinct cellular types after traumatic brain injury: an in situ hybridization and immunocytochemical study. Acta Neuropathol (Berl) 100:196-204

43. Gahm C, Holmin S, Mathiesen T 2000 Temporal profiles and cellular sources of three nitric oxide synthase isoforms in the brain after experimental contusion. Neurosurgery 46:169-177

44. Javeshghani D, Magder S 2001 Presence of nitrotyrosine with minimal inducible nitric oxide synthase induction in lipopolysaccharide-treated pigs. Shock 16:304-311

45. Brovkovych V, Patton S, Brovkovych S, Kiechle F, Huk I, Malinski T 1997 In situ measurement of nitric oxide, superoxide and peroxynitrite during endotoxemia. J Physiol Pharmacol 48:633-644

46. Halliwell B 1997 What nitrates tyrosine? Is nitrotyrosine specific as a biomarker of peroxynitrite formation in vivo? FEBS Lett 411(2-3):157-160

47. Kirsch M, Lehnig M, Korth HG, Sustmann R, de Groot H 2001 Inhibition of peroxynitrite-induced nitration of tyrosine by glutathione in the presence of carbon dioxide through both radical repair and peroxynitrate formation. Chemistry 7:33133320 